\title{
ANALISIS KESULITAN GURU MATEMATIKA DALAM PEMBELAJARAN DARING DI ANGKOLA JULU
}

Oleh :

\author{
Rapika Hafsyah Nasution" ${ }^{1)}$, Muhammad Syahril Harahap2), Nunik Ardiana ${ }^{3)}$ \\ Pendidikan Matematika, Institut Pendidikan Tapanuli Selatan \\ Email : Rapikanasution84@gmail.com
}

\begin{abstract}
Abstrak
Tujuan penelitian ini adalah untuk mengetahui kesulitan guru matematika dalam pembelajaran online pada Covid - 19 periode di Angkola Julu.Pendekatan penelitian menggunakan deskriptif kualitatif dengan 3 orang guru matematika.Angket dan wawancara digunakan dalam pengumpulan data dan triangulasi digunakan untuk memeriksa keabsahan data. Analisis data meliputi reduksi data, penyajian data, dan penarikan kesimpulan. Hasil penelitian menunjukkan kesulitan guru matematikadalam menggunakan berbagai media, melakukan Tanya jawab, mengatasi masalah siswa dalam penguasaan mata pelajaran, memberikan pemahaman mata pelajaran, menerapkan tujuan pembelajaran, kesulitan dalam mengoperasikan komputer, membangkitkan motivasi siswa, kesulitan mengetahui penguasaan mata pelajaran siswa, kesulitan mengakses internet, dan kesulitan mengatur waktu.
\end{abstract}

\section{Kata kunci $\quad$ :Kesulitan Matematika Guru, Pembelajaran Daring}

\section{PENDAHULUAN}

Pendidikan merupakan salah satu hal yang sangat penting dalam kehidupan manusia, pendidikan berkembang begitu pesat sehingga menuntut setiap orang untuk menyesuaikan diri dengan perkembangan zaman terutama anak - anak usia pelajar yang harus menempuh pendidikan untuk bekal di kehidupan masa depannya. Pembelajaran adalah proses interaksi peserta didik dengan pendidik dan sumber belajar pada suatu lingkungan belajar. Kata pembelajaran merupakan perpaduan dari dua aktivitas belajar mengajar.

Awal tahun 2020 telah terjadi pandemi virus corona yang mewabah di seluruh dunia termasuk Indonesia.Pandemi COVID-19 (Corona Virus Disease) memberikan dampak pada banyak pihak, kondisi ini sudah merambah pada dunia pendidikan, pemerintah pusat sampai pada tingkat daerah memberikan kebijakan untuk meliburkan seluruh lembaga pendidikan. Pembelajaran dilakukan tidak secara tatap muka sesuai dengan kebijakan yang ditetapkan oleh pemerintah yaitu penerbit surat edaran nomor 15 tahun 2020 yang berisi Sistem pembelajaran Online jarak jauh atau disebut dengan istilah " daring” yang berarti dalam jaringan sebagai upaya memutus mata rantai penyebaran COVID-19 (Kemdikbud, 2020);(Kelana \& Pratama, 2019 dalam Medita Ayu Wulandari, dkk., 2020 ).

Pembelajaran secara daring merupakan cara baru dalam proses belajar mengajar yang memanfaatkan perangkat elektronik khusunya internet dalam penyampaian belajar. Perubahan pembelajaran dari tatap muka menjadi daring terjadi secara mendadak, memunculkan berbagai macam kesulitan guru melasanakan pembelajaraan daring. Kondisi tersebut jika dibiarkan begitu saja, maka akan merugikan peserta didik, guru yang bersangkutan, pihak sekolah, masyarakat, dan negara secara umum. Maka dari itu peneliti tertarik mengambil judul "Analisis Kesulitan Guru Matematika Dalam Pembelajaran Daring di Angkola Julu.

\section{METODE PENELITIAN}

Metode penelitian adalah tata cara yang digunakan dalam melaksanakan penelitian untuk mencari jawaban dan pemecahan masalah. Sugiyono (2014:3) berpendapat bahwa "Metode penelitian pada dasarnya merupakan cara ilmiah untuk mendapatkan data dengan tujuan dan kegunaan tertentu".Penelitian ini penulis menggunakan metode penelitian kualitatif. Penelitian kualitatif adalah "penelitian yang menghasilkan data deskriptif yaitu yang menggunakan suatu sifat, perbuatan, tingkah laku yang diamati”,(Wassahua, 2016). Menurut Sukmadinata (2011:72) 
berpendapat bahwa "Penelitian deskriptif adalah suatu bentuk penelitian yang paling dasar, ditujukan untuk mendiskripsikan atau menggambarkan fenomena - fenomena yang bersifat alamiah ataupun rekayasa manusia"

Objek adalah permasalahan yang diinvestigasi dalam penelitian.Objek penelitian ini adalah kesulitan guru matematika dalam pelaksanaan pembelajaran daring. Bungin (2012 : 111 ) berpendapat bahwa "Informan adalah orang yang diperkirakan menguasai dan memahami data, informasi, ataupun fakta dari suatu objek penelitian. Peneliti menetapkan informan yaitu guru matematika di Angkola Julu. Teknik pengumpulan data yang penulis gunakan dalam penelitia ini sebagai berikut:

Angket

Angket merupakan sejumlah pertanyaan tertulis yang diberikan kepada responden untuk menggali informasi dan data terkait masalah penelitian yang sedang dikaji. Sukmadinata (2010:219) menyatakan bahwa,"angket (questionnaire) merupakan suatu teknik atau cara pengumpulan data secara tidak langsung (peneliti tidak langsung bertanya-jawab dengan responden). Dalam peneletian ini peneliti menggunakan angket tertutup sebagai teknik pengumpulan data untuk mendapatkan faktor kesulitan guru dalam pembelajaran daring. Adapun kisi - kisi angket yang akan diberikan adalah sebagai berikut.

\section{Tabel 1}

Kisi - Kisi Kesulitan Guru Pembalajaran Daring

\begin{tabular}{llll}
\hline \multirow{2}{*}{ NO } & Langkah - Langkah & Nomor Item & Jumlah \\
\hline 1 & Internal & $\begin{array}{l}1,2,3,4,5,6,7,8,9,10,11 \\
12,13,14,15,16,\end{array}$ & 16 \\
\hline 2 & Eksternal & $17,18,19,20$ & 4 \\
\hline & Jumlah & & 20
\end{tabular}

Dalam penelitian ini, peneliti menggunakan skala likert untuk mengukur respon guru terhadap kesulitan dalam pembelajaran daring.Angket respon guru ini disusun dengan empat alternatif jawaban yaitu, selalu, sering, kadang-kadang, dan tidak pernah.

\section{Wawancara}

Wawancara (interview) merupakan salah satu bentuk teknik pengumpulan data yang banyak digunakan dalam penelitian deskriptif kualitatif sukmadinata (2010:216). Menurut sugiyono (2014:188) menganyakan bahwa "wawancara merupakan teknik pengumpulan data dimana pewawancara (peneliti atau yang diberi tugas melakukan pegumpulan data) dalam pengumpulan data mengajukan suatu pertanyaan kepada yang diwawancarai.

\section{Dokumen}

Dokomen merupakan pengambilan data yang diproses melalui dokumen-dokumen. Dokumentasi dipakai untuk mengumpulkan data dari sumber - sumber dokumen yang mungkin atau bahkan berlawanan dengan hasil wawancara Harsono, 2008:165)

Keabsahan data dalam penelitian ini ditentukan dengan menggunakan triangulasi. Teknik analisis data yaitu reduksi data, penyajian data dan penarikan kesimpulan atau verifikasi..

\section{HASIL DAN PEMBAHASAN}

Guru matematika di Kecamatan Padangsidimpuan Angkola Julu terdiri dari 10 orang dari 8 desa yang berada di Angkola Julu. Berdasarkan penelitian yang dilakukan oleh peneliti di Kecamatan Padangsidimpuan Angkola Julu dengan topik penelitian "Analisis Kesulitan Guru Matematika dalam Pembelajaran Daring di Angkola Julu”. Adapun kesulitan guru matematika di Desa Joring lombang, Batu Layan, Rimba Soping, Mompang, Simatohir, Simasom, dan Pintu Langit menunjukkan dari keseluruhan angket yang dibagikan dengan jumlah rata-rata 66,125 berada pada kategori sangat sulit

Sesuai dengan hasil penelitian yang dilaksanakan terkait kesulitan guru matematika di Angkola Julu, maka dapat dilihat pada tabel sebagai berikut: 
JURNAL MathEdu (Mathematic Education Journal) http://journal.ipts.ac.id/index.php/MathEdu

Tabel 2

Presentasi kesulitan guru matematika di Angkola Julu

\begin{tabular}{clccc} 
NO & Nama Guru & Jumlah & Nilai & Kategori kesulitan \\
\hline 1 & LHN & 52 & 65 & Sulit \\
\hline 2 & PH & 53 & 66,25 & Sangat Sulit \\
\hline 3 & EYS & 49 & 61,25 & Sulit \\
\hline 4 & RM & 50 & 62,5 & Sulit \\
\hline 5 & ESS & 52 & 65 & Sulit \\
\hline 6 & ILS & 56 & 70 & Sangat Sulit \\
\hline 7 & NH & 55 & 68,75 & Sangat Sulit \\
\hline 8 & RH & 56 & 70 & Sangat Sulit \\
\hline 9 & NDH & 54 & 67,5 & Sangat Sulit \\
\hline 10 & NDES & 57 & 71,25 & Sangat Sulit \\
\hline & Total & 534 & 661,25 & Sangat Sulit
\end{tabular}

Berdasarkan hasil angket di atas kesulitan guru matematika terkait dengan pelaksanaan pembelajaran daring terlihat dari jawaban hasil angket yang diberikan kepada 10 guru matematika yang berada di Angkola Julu, diperoleh informasi bahwa kesulitan guru matematika berdasarkan kategori sangat sulit, sulit, cukup sulit, tidak sulit, kesulitan dalam melaksanakan pembelajaran daring.

\section{a. Hasil Angket Guru Matematika di Angkola Julu}

Penelitian ini bertujuan untuk mengetahui besarnya tingkat kesulitan guru matematika di Angkola Julu selama pembelajaran daring. Berdasarkan hasil pembangian angket yang dilakukan peneliti dari 20 item pertanyaan dipaparkan sebagai berikut :Berdasarkan pernyataan pertama dari 10 guru matematika 8 (80\%) menjawab "sering" dan 2 (20\%) menjawab "kadang-kadang". Berdasarkan dari 10 guru jawaban terbanyak yaitu $8(80 \%)$ sering merasa kesulitan mengggunakan media pembelajaran yang bervariasi.Berdasarkan pernyataan kedua dari 10 guru matematika 3 (30) menjawab "sering" dan 7 (70\%) menjawab "kadang-kadang". Berdasarkan dari 10 guru jawaban terbanyak yaitu $7(70 \%)$ kadang-kadang merasa kesulitan membuat RPP ketika hendak melaksanakan pembelajaran daring. Berdasarkan pernyataan ketiga dari 10 guru matematika 7 (70\%) menjawab "sering" dan 3(30\%) menjawab "kadang-kadang". Berdasarkan dari 10 guru tersebut jawaban terbanyak yaitu 7 (70\%) sering mengalami kesulitan menggunakana metode Tanya jawab. Sejalan dengan pendapat (erfan \& ratu 2018) cara siswa menjawab atau jawaban yang diharapkan dari siswa ditentukan oleh tingkat dan jenis pertanyaan yang diajukan oleh pendidik, apakah pertanyaan yang diajukan tersebut termasuk dalam tingkat ingatan, pemahaman, analisis, atau evaluasi.Berdasarkan pernyataan empat dari 10 guru matematika 2 (20\%) menjawab "selalu" $6(60 \%)$ menjawab "sering" dan 2 (20\%) menjawab "kadang-kadang". Berdasarkan dari 10 guru jawaba terbanyak yaitu $6(60 \%)$ sering mengalami kesulitan mengatasi permasalahan siswa yang sulit dalam memahami materi pelajaran matematika.Berdasarkan pernyataan lima dari 10 guru matematika 1 (10\%) menjawab "selalu", 8 (80\%) menjawab "sering" dan $1(10 \%)$ menjawab "kadang-kadang" dari 10 guru tersebut jawaban terbanyak yaitu $8(80 \%)$ sering merasa kesulitan memberikan pemaham pelajaran matematika kepada siswa.Berdasarkan pernyataan enam dari 10 guru matematika 4(40) menjawab "sering" dan 6 (60\%) menjawab "kadang-kadang". Berdasarkan dari 10 guru jawaban terbanyak yaitu 6 (60\%) kadang-kadang kesulitan berkomunikasi dengan baik kepada siswa ketika pembelajaran daring sedang berlangsung.Berdasarkan pernyataan ketuju dari 10 guru matematika menjawab $6(60 \%)$ "sering" dan 3 (30) "kadang-kadang". Berdasarkan dari 10 guru jawaban terbanyak yaitu 7 (70\%) sering Guru kesulitan merumuskan tujuan pembelajaran matematika yang harus dicapai oleh siswa Berdasarkan pernyataan delapan dari 10 guru matematika menjawab 1 (10\%) "selalu", 2 (20\%) "sering”, dan 7 (70\%) " kadang-kadang. Berdasarkan 10 dari 10 guru jawabn terbanyak yaitu 7 (70\%) kadang-kadang Guru membuat ujian saat pembelajaran daring. Berdasarkan pernyataan sembilan dari 10 guru matematika menjawab 3(30\%) "selalu", 4 (40\%) "sering) dan 3 (30\%) "kadang-kadang". Berdasarkan dari 10 guru jaawaban terbanyak 4 (40\%) sering kesulitan menemukan metode belajar yang menyenangkan materi pelajaran matematika saat 
daring.Berdasarkan pernyataan sepuluh dari 10 guru matematika menjawab $10(100 \%)$ "tidak pernah" artinya guru matematika di angkola julu sebelumnya belum pernah melakukan pembelajaran berbasis daring. Berdasarkan pernyataan sebelas dari 10 guru matematika jawaban 6 (60\%) "sering" dan 4 (40\%) "kadang-kadang". Berdasarkan dari 10 guru jawaban terbanyak 6 $(60 \%)$ sering merasa bosan dengan adanya pembelajaran daring.Berdasarkan pernyataan dua belas dari 10 guru matematika 7 (70\%) menjawab "sering" dan 3 (30\%) "kadang-kadang". Berdasarkan dari 10 guru jawaban terbanyak 7 (70\%) sering kesulitan mengoperasikan komputer dengan baik.Berdasarkan pernyataan tiga bealas dari 10 guru matematika menjawab 3 (30\%) "selalu", 5 $(50 \%)$ "sering" dan $2(20 \%)$ "kadang-kadang". Berdasarkan dari 10 guru jawaban terbanyak 5 $(50 \%)$ sering kesulitan mengetahui kemampuan pemahaman matematika siswa selama daring.Berdasarkan pernyataan empat belas dari 10 guru matematika menjawab $8(80 \%)$ "selalu", $2(20 \%)$ "sering". Berdasarkan dari 10 guru jawaban terbanyak $8(80 \%)$ selalu mengalami kesulitan dalam membangkitkan motivasi belajar siswa di masa COVID-19 saat ini. Motivasi adalah dorongan usaha memperoleh agar bergerak hatinya untuk melakukan kemauan belajar sehingga mencapai hasil belajar yang baik (Purwanto 2017). Berdasarkan pernyataan lima belas dari 10 guru matematika menjawab 4 (40\%) "sering", dan $6(60 \%)$ "kadang-kadang". Berdasarkan dari 10 guru jawaban terbanyak $6(60 \%)$ kadang-kadang mengalami kesulitan ketika proses pelajaran matematika saat daring. Berdasarkan pernyataan enam belas dari 10 guru matematika menjawab 4 (40) "sering" dan 6 (60\%) "kadang-kadang". Berdasarkan dari 10 guru jawaban terbanyak $6(60 \%)$ kadang-kadang kesulitan mengakses internet dengan baik dalam proses pembelajaran daring.Berdasarkan pernyataan tujuh belas dari 10 guru matematika menjawab 4 (40\%) "sering" dan 6 (60\%) "kadang-kadang". Berdasarkan dari 10 guru jawaban terbanyak 6 (60\%) kadang-kadang kesulitan menggunakan aplikasi tertentu dalam melakukan pembelajaran matematika.Berdasarkan pernyataan delapan belas dari 10 guru matematika menjawab 5(50\%) "selalu", 4 (40\%) "sering, dan 1 (10\%) "kadang-kadang". Berdasarkan dari 10 guru jawaban terbanyak $5(50 \%)$ selalu mengalami kesulitan dalam alokasi waktu pembelajaran daring.Berdasarkan pernyataan Sembilan belas dari 10 guru matematika menjawab $2(20 \%)$ "sering" dan 8 (80\%) "kadang-kadang". Berdasarkan dari 10 guru jawaban terbanyak $8(80 \%)$ kadang-kadang memiliki kouta internet atau jaringan internet yang memadai dalam melakukan proses pembelajaran daring.Berdasarkan pernyataan dua puluh dari 10 guru matematika menjawab 3 (30\%) "sering", menjawab 7 (70\%) "kadang-kadang". Berdasarkan dari 10 guru jawaban terbanyak $8(80 \%)$ kadang-kadang menggunakan sarana dan prasarana yang disediakan oleh pihak sekolah, seperti komputer, tablet dll.

\section{b. Hasil Wawancara Guru Matematika di Angkola Julu}

Untuk memperkuat hasil angket yang telah disebarkan kepada guru, maka peneliti melakukan wawancara kepada 3 orang guru matematika di Angkola Julu. Berikut hasil dari wawancara guru matematika di Angkola Julu:

Berdasarkan hasil penelitian dapat diketahui bahwa 65 kategori sulit, ibu ESS mengatakan beberapa kesulitan dalam melaksanakan pembelajaran daring di angkola julu. Sering Kesulitan menggunakan media pembelajaran yang bervariasi, sering kesulitan menggunakan metode tanya jawab dalam pembelajaran daring, selalu kesulitan memberikan pemahaman pelajaran matematika siswa, sering kesulitan merumuskan tujuan pembelajaran matematika siswa yang harus dicapai oleh siswa, sering kesulitan dalam mengoperasikan komputer dengan baik, sering kesulitan mengetahui pemahaman siswa selama pembelajaran daring, kesulitan berkomuniakasi dengan baik kepada siswa saat pembelajaran daring, sering kesulitan kesulitan ketika proses pembelajaran daring dan sering kesulitan alokasi waktu pembelajaran daring. (Hal ini sejalan dengan hasil angket ibu ESS)

Berdasarkan hasil penelitian dapat diketahui bahwa 66,25 kategori sangat sulit, ibu PH mengatakan beberapa kesulitan dalam melaksanakan pembelajaran daring di angkola julu. Sering kesulitan menggunakan media pembelajaran yang bervariasi, sering kesulitan menggunakan metode tanya jawab dalam proses pembelajaran daring, sering kesulitan mengatasi permasalahan siswa yang sulit dalam proses pembelajaran daring, sering kesulitan berkomunikasi dengan baik kepada siswa ketika pembelajaran daring sedang berlangsung, sering kesulitan menemukan belajar yang menyenangkan materi pelajaran matematika saat daring, sering kesulitan mengetahui pemahaman matematika siswa selama daring, sering kesulitan membangkitkan motivasi belajar siswa di masa covid 19 saat ini, sering kesulitan ketika proses pembelajaran daring pelajaran 
matematika, sering kesulitan mengakses internet dengan baik dalam proses pembelajaran daring, selalu kesulitan dalam alokasi pembelajaran daring. (Hal ini sejalan dengan hasil angket ibu $\mathrm{PH}$ ).

Berdasarkan hasil penelitian dapat diketahui bahwa 68,75 kategori sangat sulit, ibu NH mengatakan beberapa kesulitan dalam melaksanakan pembelajaran daring di angkola julu. Sering mengalami kesulitan menggunakan media pembelajaran yang bervariasi, sering kesulitan menggunakan metode tanya jawab dalam proses pembelajaran daring, sering kesulitan mengatasi permasalahan siswa yang sulit dalam memahami materi pelajaran matematika, sering kesulitan memberikan pemahaman pelajaran matematika kepada siswa, sering kesulitan berkomunikasi dengan kepada siswa ketika pembelajaran daring sedang berlangsung, sering merasa bosan dengan adanya pembelajaran daring, sering kesulitan mengoperasikan komputer dengan baik. Sering kesulitan mengetahui pemahaman matematika siswa selama daring, selalu kesulitan membangkitkan motivasi belajar siswa di masa covid-19 saat ini, selalu mengalami kesulitan ketika proses pembelajaran daring pelajaran matematika, selalu mengalami kesulitan dalam alokasi waktu pembelajaran matematika. ( Hal ini sejalan dengan hasil angket ibu NH).

Berdasarkan hasil penelitian dapat diketahui bahwa kesulitan guru matematika di Angkola Julu saat pembelajaran daring salah satunya mengenai media pembelajaran yang digunakan selama melaksanakan pembelajaran daring dikarenakan ada beberapa guru yang merupakan pengguna pemula dalam beberapa media pelajaran berbasis teknologi komputer dan internet. Penguasaan media pembelajaran sangat penting dilakukan karena dalam penggunaan media pembelajaran online, pembelajaran bersifat mandiri dan memiliki interaktif tinggi sehingga dapat meningkatkan ingatan, memberikan pengalaman belajar melalui teks, vidio, dan animasi yang dibuat sehingga informasi yang akan disampaikan dapat lebih mudah dipahami dan dipelajari oleh siswa (Sunarti, 2020).

Untuk meningkatkan motivasi prestasi belajar siswa di tengah pandemi COVID 19, diperlukannya peran guru yang kreatif. Seperti dikatakan Nopiyanto (2020) dan Wardoyo (2020) Guru yang kreatif dalam mampu melakukan proses pembelajaran secara efektif dengan menggabungkan berbagai konsektual intruksional bahan, strategi pengajaran, pembelajaran media dan pengalaman kehidupan nyata. Pembelajaran daring dibutuhkan alokasi waktu yang cukup agar guru dapat memberikan pemahaman materi kepada siswa. Pembelajaran matematika diharapkan berakhir dengan sebuah pemahaman siswa yang komprehensif dan holistik tentang materi yang telah disajikan dalam mengajar (Sardiman, 2008).

\section{KESIMPULAN}

Berdasarkan hasil penelitian yang dilakukan dapat diambil kesimpulan, kesulitan guru matematika dalam pembelajaran daring di Angkola Julu yaitu sebagai berikut:

1. Sebagian besar guru kesulitan menggunakan media pembelajaran yang bervariasi $(80 \%)$

2. Sebagianbesarguru kesulitan menggunakan metode tanya jawab dalam proses pembelajaran daring $(70 \%)$

3. Sebagian besarguru kesulitan mengatasi permasalahan siswa yang yang sulit dalam memahami materi pelajaran matematika $(60 \%)$

4. Sebagian besargurukesulitan memberikan pemahaman pelajaran matematika kepada siswa $(80 \%)$

5. Sebagian besarguru kesulitan merumuskan tujuan pembelajaran matematika yang harus dicapai oleh siswa $(70 \%)$

6. Sebagian besar guru kesulitan mengoperasikan komputer dengan baik $(70 \%)$

7. Setengah guru kesulitan mengetahui pemahaman siswa selama pembelajaran daring (50\%)

8. Sebagian besarguru kesulitan membangkitkan motivasi siswa belajar siswa dimasa COVID 19 saat ini $(80 \%)$

9. Sebagianbesarguru kesulitan ketika proses pembelajaran daring (60\%)

10. Setengah guru mengalami kesulitan ketika proses pembelajaran matematika saat daring $(60 \%)$

11.Setengah guru kesulitan dalam alokasi waktu pembelajaran daring $(50 \%)$

\section{SARAN}

1. Kepada guru matematika di Angkola Julu agar lebih kreatif dan meningkatkan kemampuannya dalam menyusun dan merancang pembelajaran berbasis online khususnnya pelajaran matematika 
2. Kepada para siswa agar lebih giat membaca materi-materi yang diberikan oleh guru serta siswa yang tidak melakukan pembelajaran online harus lebih giat belajar. Dan yang jaringnnya yang kurang bagus agar mencari jaringan yang memadai.

3. Kepada Pemerintah diharapkan solusi yang sangat tepat dan efektif terhadap permasalahan pembelajaran daring selama pademi.

\section{REFERENSI}

Ahmad Susanto. 2013. Teori Belajar dan Pembelajaran di Sekolah Dasar.Jakarta :Kencana

Anugrah, Andiri. (2020) Hambatan, Solusi Dan Harapan : Pembelajaran Daring Selama Masa Pandemi COVID-19 Oleh Guru Sekolah Daasar. Jurnal pendidikan dan kebudayaan. Vol.10, No.3

Ariesca, Yuni, dkk. Analisis Kesulitan Guru Pada Pembelajaran Berbasis Online Di SDN SeKecamatan Muluk.Jurnal progress pendidikan, vol. 2, No.1 Januari 2021.

Tanjung, Henni Paujia., Ardiana, Nunik., Lubis, Roslian., (2020). Efektivitas Model Problem Posing Terhadap Kemampuan Pemecahan Masalah Matematis Siswa Di SMK Swasta Teruna Padangsidimpuan.Jurnal MathEdu (Mathematis Education Jurnal). Vol.3 No. 3

Fauzi, azra, dkk .( 2019). Kesulitan Guru Pada Pembelajaran Matematika Di Sekolah Dasar.Jurnal Immilah Mandala Education. Vol. 6 No. 1

Harahap, Muhammad Syahril., \& Rahmad, Fauzi., (2017) Modul Pembelajaran Matematika Berbasis WEB. Jurnal Education and development STKIP Tapanuli Selatan, Vol. No.5.

Iskandar Agung., . 2017. Kompetensi guru. Jakarta: pustaka.

Juliansyah Noor. 2016. Metodologi Penelitian. Jakarta : Kencana

Jayanti, Indriani., Arifin, Nurdin., \& Nur, Dedi Rahman.,. (2020). Analisis Faktor Internal Dan Eksternal Kesulitan Belajar Matematika Di Sekolah Dasar.Jurnal Pendidikan Vol.1/Issue 1

Kirom, askhabul. (20170. Peran guru dan peserta didik dalam proses pembelajaran berbasis Multikultural. Jurnal Pendidikan Agama Islam. Vol. 3. No. 1

Lamote, Hasrin. (2017). Kesulitan -Kelusitan Guru Matematika Dalam Melaksanakan Pembelajaran Kurikulum 2013 Di Madrasah Aliyah DDI Labibia.Jurnal Al-Ta'dib. Vol. 10 No.1

Mirati, Luthfiana. (2015). Analisis Kesulitan Belajar Matematika Pada Topic Logika Pada Siswa SMK Muhammadiyah 3 Klaten Utara.Jurnal Pendidikan Matematika. Vol. 2. No. 1

Nana Syaodih Sukmadinata.2010. Metode Penelitian. Bandung : Remaja Rosdakaryaa

Pane, Aprida, And Muhammad Darwis Dasopang. (2017). Belajar dan Pembelajaran.Jurnal kajian ilmu-ilmu keislamanVol. 03. No.2

Puspitasari, Nimas.(2020). Analisis Proses Pembelajaran Dalam Jaringan Masa Pandemi Covid 19 Pada Guru Sd Negeri Dukuhwaru 01. Jurnal Magistra. Vol. 11. No. 2

Rigianti, Hendry Aditia. (2020). Kendala Pembelajaran Daring Guru Sekolah Dasar Di Kabupaten Banjarnegara.Jurnal Elementary School. Vol.7. No. 2

Rijali, Ahmad.(2018). Analisis Data Kualitatif.Jurnal Alhsdharah. Vol.17.No .33

Sae. D. B. And H.Sihotang.(2020). Analisis Hambatan Guru MIPA Dalam Pembelajarab Daring Di SMAS KR. Rantepao Di Masa Pandemi Covid 19.Jurnal Edumatsains, special Issue, 1

Sugiyono.2016. Metode Penelitian.Bandung : Alpabeta.

Syaiful Bahri Djamarah. 2005. Guru Dan Anak Didik Dalam Interaksi Edukatif. Jakarta: Renaka Cipta

Sugiyono. 2014. Metode Penelitian. Bandung : Alfabeta

Syaiful Bahri Djamarah. 2010. Guru \& Anak Didik. Jakarta : Renaka Cipta

Syaiful Sagala. 2011. Kemampuan Propesional Guru dan Tenaga Kependidikan.Bandung : Alpabeta

Wardoyo, C., Herdiani, A., Susilowati, N., \& Harahap, M. S. (2020). Professionalism and professionalization of early stage teachers in higher education. Journal of Applied Research in Higher Education. https://doi.org/10.1108/JARHE-04-2019-0100 
ISSN. 2621-9832

JURNAL MathEdu (Mathematic Education Journal) http://journal.ipts.ac.id/index.php/MathEdu Vol. 4 No. 2 Juli 2021

Wibowo, Endro, And jailani. (2014). Analisis Kesulitan Guru Matematika SMP Dalam Pengembangan Propesi Di Kabupaten Wonososbo.Jurnal Riset Pendidikan Matematika, Vol. 1. No.2

Wuladari, Medita ayu, dkk.Analisis Pembelajaran Daring Pada Guru Sekolah Dasar Di Era CAOVID-19.Jurnal ilmiah UPT P2M STKIP Siliwangi. Vol.7, NO.2 November 2020. 